\title{
TIME CONSUMPTION AND PRODUCTIVITY IN WOOD \\ EXTRACTION USING TRADITIONAL CABLE CAR
}

Ylli KORTOÇI (i) 1

\section{Mirvjena KORTOÇI}

1 University of Prizren "UKSHIN HOTI", Faculty of Life and Environmental Sciences, ylli.kortoci@uni-prizren.com

2 University of Prizren "UKSHIN HOTI”, Faculty of Life and Environmental Sciences, mirvjena.kortoci@ uni-prizren.com *Correspondent Author.

\section{Article history:}

Submission 10 April 2021

Revision 04 June 2021

Accepted 11 August 2021

Available online 31 August 2021

\section{Keywords: \\ Wood Extraction, \\ Working Times, \\ Avoidable Delay, \\ Unavoidable Delay, \\ Productivity.}

DOI:

https://doi.org/10.32936/pssj.v5i2.239

\begin{abstract}
A b s t r a c t
Forests are a very important component for the environment in Albania considering the fact that they occupy more than $36 \%$ of the country's surface. The evaluation of the working time consumption and productivity of the various sub-phases of wood extraction work, in a beech forest in Albania, with traditional methods and old equipment's, was considered of interest in this study to highlight the weaknesses to be corrected. Considering the slope in our study site, a traditional cable car Austrian Type R-Gander (A 6832 SULZ) manufactured in 1985 was used for the extraction of timber. Trunks from a distance of 800 - $900 \mathrm{~m}$ were extracted using this equipment. The operating team consisted of 3 workers. 10 - 15 working days are required for the assembly and disassembly of the equipment. During the work performed, data regarding working times were collected, paying special attention to dead times, where avoidable times are high $61,0 \%$. The extracted volume was $31.46 \mathrm{~m} 3$, which corresponds to a weight of $41.82 \mathrm{t}$.
\end{abstract}

\section{Introduction}

Substantial amounts of Albanian forests are located in mainly mountainous areas and on very steep terrains, most of the forests are located in those areas where the average slope is around 15$30^{\circ}$. More than half the volume is located in the forests area at an altitude of 1500-1850 $\mathrm{m}$ above sea level. The distribution of forest species in the country can be as follows: beech accounts for about $21.6 \%$ of the surface and about $47 \%$ of the total wood volume; conifers, $19.6 \%$; oaks $36.6 \%$ and $22.3 \%$ for other species. (Kortoci and Kortoci (Kellezi), 2020). Ninety percent of Albanian beech forests are high forests, and only $10 \%$ are coppice. Wood extraction has increased over time from the early colonial period to 1947 . (Dangwal, 2005).

As consequence of mechanization, the development of timber harvesting has been successful in recent decades when productivity has raised and costs have decreased. However, despite the general development of forest machinery technology, there is no harvesting method for steep terrain. (Kaakkurivaara and Kaakkurivaara, 2018). It is important to investigate other solutions to improve the productivity and cost-efficiency of harvesting. (Kaakkurivaara and Kaakkurivaara, 2018). Limited investment willingness is a factor that influence the determination of suitable harvesting methods in forestry. (Kaakkurivaara and Kaakkurivaara, 2018). The animals or machinery that can traverse distances of 1000 - $2000 \mathrm{~m}$ has always performed the extraction of wood material in Albania.

Some terrain features conditions the possibility the use of cable cars is, and in general the slope, the line profile, and the availability of the roads, in addition to the available persons who are able to mount and use the cable car. The extraction of timber using cable car is almost inexistent although this method is very suitable in our forest terrains. The cable car taken in consideration in this study is the only one existent in Albania in this moment and used in forest utilization.

The aim of this study is to determine the working times and productivity during wood extraction work to create an idea about the efficiency of this old mechanism. 


\section{Literature Review}

In the planning of forest utilization, the factors that determine the choice of means and of the work system to be used are many. The infrastructures present (in particular roads), the professionalism of the operators, the efficiency of the works management and the equipment available for the logging operation can be modified, while other conditions, such as the intensity of the cut, the size of the material to be use or the characteristics of the terrain (slope and accidental) are rather rigid or not modifiable (Civitarese et al., 2006).

In the case of forests located on slopes of 60 to 80 percent traditional cable car skylines are used. Daily man yields 5-8 m3 in the case of cable car skylines (Baldini and Pollini, 1998). The Gantner long-distance skyline used in the study was mounted on a sled. Gantner skylines are powerful and productive. It is an important machine for timber transportation at long distances. These machines are used where the transport distance is long or the road density is low (Acar et al., 2005).

In Turkey, Gantner cable cranes have been in use since the late 1950's. The actual share of cable systems is not very high in total timber extraction. However, in mountainous parts of Turkey such as the study area, this is the only possible system of timber extraction. (Ozturk and Senturk, 2006). Productivity of Gantner skyline was 5.01 m3/hour (Eker and Acar, 1995).

Generally, traditional long-distance gravity cable systems have a daily productivity of 20 to $25 \mathrm{~m} 3$ has been reported (Heinrich, 1998). In Austria, 14.48 percent of the timber is harvested with cable systems. This ratio is 1.769 million $\mathrm{m} 3$ yield. The amount of timber harvested with cable logging systems has doubled over the last ten years (Trzesnowski, 1998).

Factors affecting productivity include machine size and properties, equipment configuration, stand and site conditions, forest management objectives, and operator capabilities. The effects of these factors have been studied widely over the last 25 years (Malinen at al., 2016).

A traditional cable car was used for the concentration and clearing of the felled trunks in Librazhd, for the assembly and disassembly required 10-15 working days. This machine is the only one that exists in all of Albania. (Kortoci, 2009).

In Eastern European countries, at the beginning of the economic transformation, when the private forestry services sector was being established, the equipment acquired was of low technical quality. Increasing competition in the forestry services set off a search for new technological solutions to decrease labor costs and increase work efficiency. The rate of investment for mechanization also depends on the regional availability of skilled workers. In mountainous regions, cable yarding systems are also used. (Tadeusz et al., 2017).

\section{Materials and methods}

\subsection{Study site}

Librazhd forest is a high forest where beech is the dominant species and covers an area of about $95 \%$. It is an old forest with an age of about 100 years, and the exploiting company intervened with clear cutting, in an area of about 20 ha. The diameter of the trees was larger than $40 \mathrm{~cm}$, and the height reached about 20-25 $\mathrm{m}$. The slope of the site is about $35-50 \%$ with holes and stones in it. The maximum altitude above sea level is $2253 \mathrm{~m}$.

The geographical position, the relief configuration, the absolute altitude above sea level, and the distance from the Adriatic Sea are characteristic of the presence of a continental climate, with a very cold period of winter. In addition to the cold winter, Librazhd is also very wet, while the summer is short, hot and very dry. Average annual air temperatures range between $7.5^{\circ} \mathrm{C}-12$ ${ }^{\circ} \mathrm{C}$, while the absolute maximum temperature recorded in July is $39.6^{\circ} \mathrm{C}$.

Average annual rainfall varies between 600 to $890 \mathrm{~mm}$. Based on the classification of land in Albanian, there are two types of land in Librazhd brown soils, and brown forest soils. From 1600 - 2000 $\mathrm{m}$ above sea level, the brown terrains are generally placed. Their typical vegetation is beech and pine forests.

\subsection{Measurements and Statistical Analysis}

During the extraction of wood material with traditional cable cars, has been collected the following data:

- Empty driving time: the time it took the carriage to move from the discharge point to the blockage in the conductor line, at the top.

- The time of detachment of the rope (hooks) and their landing: the time when the rope falls down and the piston is taken by the worker and connected to the other load.

- Return time: the time the carriage began to climb until it reached the line blocking point at the discharge point at the bottom (runway).

- Release time: the time required to lower the rope and remove the load from the hooks.

- Unavoidable dead times: Non-operative times for food, physiological needs, etc. 
- Avoidable dead times: Non-operative times when workers talk, call, etc.

- Average trees number per each transportation time.

Data on productivity were collected, calculated and analyzed. For the determination of fresh density, three samples for each single plant positioned one at the base, one at mid-height and one at the top were taken on 10 plants.

\section{Results}

In order to increase opinion through foreign exchange, Indonesia The working time analysis show a large percentage of the time "wagon going" (19\%), and "return" (17\%), because the average distance traveled was $841 \mathrm{~m}$. Measurements are made for 25 roads.

Table 1. Total values of wood extraction working times using traditional cable car.

\begin{tabular}{lc}
\hline Working times & Minutes \\
\hline Gross Total Time $(\min )$ & 399,01 \\
\hline
\end{tabular}

\begin{tabular}{lc}
\hline Net Total Time $(\mathrm{min})$ & 372,03 \\
\hline Total delay (dead) times & 69,1 \\
\hline Avoidable delay times & 26,98 \\
\hline Unavoidable delay times & 42,12 \\
\hline
\end{tabular}

Table 2. Number of trunks extracted, number of roads made by the traditional cable car, minimum and maximum distance in one working day.

\begin{tabular}{ll}
\hline No. of extracted trunks & 60 \\
\hline No. of roads made & 25 \\
\hline Average number of trunks/ road & 2,4 \\
\hline Maximum distance $(\mathrm{m})$ & 900 \\
\hline Minimum distance $(\mathrm{m})$ & 800 \\
\hline Average distance $(\mathrm{m})$ & 841 \\
\hline
\end{tabular}

For each working phase, the average time and standard deviation are find, then the average time for the road and the number of logs extracted from the forest are determined.

Table 3. Average net times per road for each sub-phase of timber extraction with traditional cable car.

\begin{tabular}{lcc}
\hline The wagon goes & For road (min) & Standard deviation \\
\hline Releases the cable & 3,00 & 0,59 \\
\hline Hook & 0,59 & 0,21 \\
\hline Collect the cable & 2,13 & 0,80 \\
\hline Returns & 1,12 & 0,40 \\
\hline Unhook & 2,67 & 0,33 \\
\hline Avoidable delay time & 3,69 & 1,32 \\
\hline Unavoidable delay time & 1,68 & 1,98 \\
\hline Total net time for road & 1,08 & 12,29 \\
\hline Total gross time per road & 14,88 & 15,96 \\
\hline
\end{tabular}

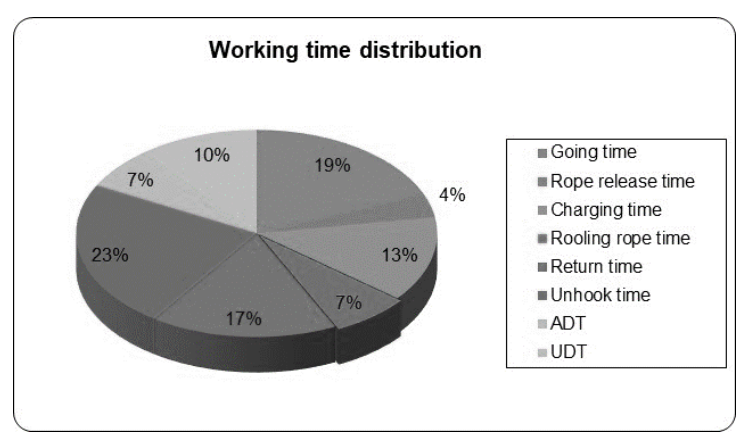

Figure 1. Distribution in percentage of average times of extraction phases of wood material with traditional cable car.

Unhook time (23\%) and going time (19\%) occupy the biggest percentage of working times with traditional cable car.
Avoidable delay times (dead times) that occupy $39 \%$ of total time are composed by "conversation" times $65 \%$ and "smoking break" of $35 \%$. 
Unavoidable delay times that occupy $61 \%$ of total time are composed of "rope problems" nearly $59 \%$ and "cable car defects" of $41 \%$.
The extracted volume was $31.46 \mathrm{~m} 3$, which corresponds to a weight of $41.82 \mathrm{t}$. Real productivity is calculated for one team and each worker, taking into account a gross working day of 4 hours. The average number of trunks extracted for road was 2,4 and the average distance spans on $841 \mathrm{~m}$.

Table 4. Real productivity in timber extraction with traditional cable car.

\begin{tabular}{|c|c|}
\hline Productivity & \\
\hline Gross hourly average productivity $\left(\mathrm{m}^{3} / \mathrm{h} /\right.$ team $)$ & 4,730 \\
\hline Hourly average production net of $\mathrm{ADT}\left(\mathrm{m}^{3} / \mathrm{h} /\right.$ team $)$ & 5,070 \\
\hline Gross hourly average productivity $(\mathrm{t} / \mathrm{h} / \mathrm{team})$ & 6,29 \\
\hline Hourly average production net of ADT $(\mathrm{t} / \mathrm{h} / \mathrm{team})$ & 8,36 \\
\hline Gross daily average productivity ( $\mathrm{m}^{3} /$ day/team) & 18,920 \\
\hline Gross daily average productivity (t/day/team) & 25,16 \\
\hline Daily average productivity net of ADT $\left(\mathrm{m}^{3} /\right.$ day $/$ team $)$ & 20,280 \\
\hline Daily average productivity net of ADT (t/day/team) & 33,44 \\
\hline Gross hourly average productivity (m3/h/worker) & 1,577 \\
\hline Hourly average production net of ADT $(\mathrm{m} 3 / \mathrm{h} /$ worker $)$ & 1.690 \\
\hline Gross hourly average productivity ( $\mathrm{t} / \mathrm{h} /$ worker) & 2,10 \\
\hline Hourly average production net of ADT $(\mathrm{t} / \mathrm{h} /$ worker) & 2,79 \\
\hline Gross daily average productivity (m3/day/worker) & 6,308 \\
\hline Gross daily average productivity (t/day/worker) & 8,40 \\
\hline Daily average productivity net of ADT (m3/day/worker) & 6,760 \\
\hline Daily average productivity net of ADT ( $\mathrm{t} /$ day/worker) & 11,16 \\
\hline
\end{tabular}

Potential productivity is calculated for both team and workers, taking into account an 8-hour gross working day. If workers were able to work longer than 4 hours in a working day, it would be understandable that productivity would be greater than real productivity. The reason why the workers lose so many times from the working day is that they live in the city far away from the forest utilization site.

Table 5. Potential productivity in timber extraction with traditional cable car.

\begin{tabular}{|c|c|}
\hline Productivity & \\
\hline Gross hourly average productivity $\left(\mathrm{m}^{3} / \mathrm{h} /\right.$ team $)$ & 4,730 \\
\hline Hourly average production net of ADT $\left(\mathrm{m}^{3} / \mathrm{h} /\right.$ team $)$ & 5,070 \\
\hline Gross hourly average productivity $(\mathrm{t} / \mathrm{h} /$ team) & 6,29 \\
\hline Hourly average production net of $\mathrm{ADT}(\mathrm{t} / \mathrm{h} / \mathrm{team})$ & 8,36 \\
\hline Gross daily average productivity ( $\mathrm{m}^{3} /$ day/team) & 37,840 \\
\hline Gross daily average productivity (t/day/team) & 50,32 \\
\hline Daily average productivity net of ADT ( $\mathrm{m}^{3} /$ day/team) & 40,560 \\
\hline Daily average productivity net of $\mathrm{ADT}$ (t/day/team) & 66,88 \\
\hline Gross hourly average productivity (m3/h/worker) & 1,580 \\
\hline Hourly average production net of ADT (m3/h/worker) & 1,690 \\
\hline Gross hourly average productivity ( $\mathrm{t} / \mathrm{h} /$ worker) & 2,1 \\
\hline Hourly average production net of $\mathrm{ADT}(\mathrm{t} / \mathrm{h} /$ worker) & 2,79 \\
\hline Gross daily average productivity (m3/day/worker) & 12,640 \\
\hline Gross daily average productivity (t/day/worker) & 16,8 \\
\hline Daily average productivity net of ADT (m3/day/worker) & 13,520 \\
\hline Daily average productivity net of $\mathrm{ADT}$ (t/day/worker) & 22,32 \\
\hline
\end{tabular}


It can be noticed from this table that the "gross daily average productivity (m3/day/team)" of $37,840 \mathrm{~m} 3$ and the "daily average productivity net of ADT (m3/day/team)" of 40,560 m3. The second productivity is higher than the first one for the simple reason that in the second process is considered that the workers complete their work without any problem and without losing a second in their performance. This is an ideal situation that is difficult to be faced in practice. The same thing can be explained for the productivity measures in tones.

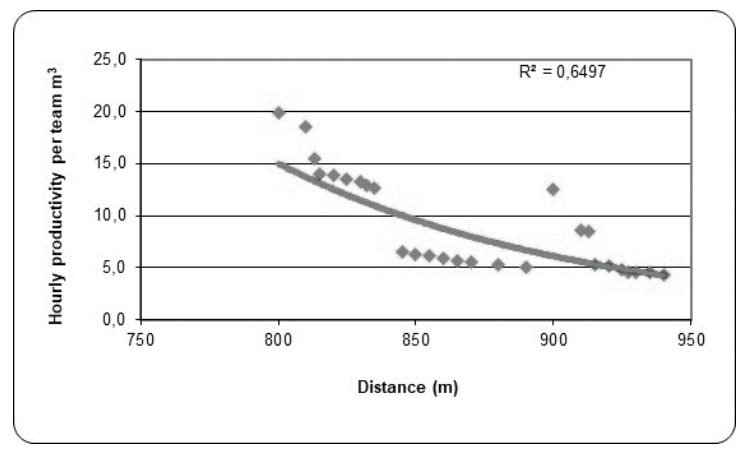

Figure 2. Correlation between timber extraction distance from forest and ADT net hourly productivity per team (m3).

There is a significant negative linear correlation between the distance and productivity. As long as the distance is lower is the productivity.

\section{Discussion}

According (Eker and Acar, 2001) the most time consuming work phase times were found to be the hooking and pulling of loaded carriage time. While in our case unhook time (23\%) and going time (19\%) occupy the biggest percentage of working times with traditional cable car. Unhook time includes also the time spend to manage the logs of the pervious load in order to make space for the following load. (Ozturk, 2006) also reports the unhook time of $24 \%$ of all time consumption.

According (Eker and Acar, 2001) total productive work times were calculated between 92.24 percent of total work time and 91.61 percent. In our case total productive work time occupies 82 percent because of the small number of operators (two of them working with the logs, hooking and unhooking and one of them managing the cable car and communicating by radio with other operators dealing with the load) and rough terrain also.

(Eker and Acar, 2001) reports the data obtained from work and time analyses where productivity values were determined between $32.24 \mathrm{~m} 3$ per day and $55.76 \mathrm{~m} 3$. In this study we can notice the "gross daily average productivity (m3/day/team)" of $37,840 \mathrm{~m} 3$ and the "daily average productivity net of ADT (m3/day/team)" of $40,560 \mathrm{~m} 3$. So the productivity can be considered normal and similar to the literature review.

About the features of conventional cable cranes output/workinghour of different types of cable cranes (Trzesnowski, 1998) reports:

Table 6. Output/working-hour of different types of cable cranes

\begin{tabular}{|c|c|c|c|}
\hline Conventional & Small & Medium & Large \\
\hline \multicolumn{4}{|c|}{ output $/ \mathrm{h}\left(\mathrm{m}^{3} / \mathrm{h}\right)$} \\
\hline $5(3-8)$ & $4(3-8)$ & $8(4-15)$ & $12(8-25)$ \\
\hline
\end{tabular}

\section{Conclusions}

This study aims to offer an idea and show the results about traditional timber extraction method by Ganter cable car to help in decision making in relation to alternative timber extraction methods. The cable crane with an 800-900 m line length was installed and three workers were engaged while in other studies for workers perform the extraction processes. The number of workers for loading and unloading operations should be increased for achieving productivity of forest skyline. 
Forest products, which have been hauled with skylines, have high quality and lose little value through log damage. Old technologies for the extraction of timber need to be substitute with more productive new ones. For example, in our case can be used light winches with autonomous engine, and plastic channels for the transport of firewood, which can be used in very steep and rocky soils.

To reduce the unproductive times of workers moving from dwellings to the forest, types of makeshift dwellings with beds and kitchens (barracks) can be built so that workers can stay there from Monday until Saturday without having to move up and down in unsuitable conditions 3-4 hours a day.

Training courses for the people working in forests are very important to educate this category with the new and adaptable technologies with Albanian mountain conditions.

A sufficient percentage of road density would favor a correct and sustainable forest management. Adequate road density also favors the use of high-level mechanisms which would lead to an improvement in the condition of forests, even to steep slopes and to improved working conditions for workers working there.

Articulated forest tractors, mobile cable car tractors, chipping machines (wood and branches) and other wood processes could be used in particular to produce clean energy from forest biomass. Eventoough (Kaakkurivaara and Kaakkurivaara, 2018) reports that there is no harvesting method for steep terrain.

\section{Acknowledgements}

We are grateful to Kole Sinani entrepreneur of the harvesting company of Librazhdi forest.

\section{References}

1. Acar, H.H., Topalak, O. and Eroglu, H. (2005). Forest skylines in Turkish forestry. Mehanizacija Sumarstva, 26(2), 137-140. Available at https://www.researchgate.net/publication/344541364 _Forest_Skylines_in_Turkish_Forestry

2. Baldini, S. \& Pollini, C. (1998). Interaction between network of services: forestry and wood harvesting systems. Proceedings of the Seminar on Environmentally Sound Forest Roads and Wood Transport. Available at http://www.nzdl.org/cgibin/library?e=d-00000-00---off-0aginfo--00-0----010-0----0---0direct-10---4--------0-01--11-en-50---20about---00-0-1-00-0--4----0-0-11-10-0utfZz-8$\underline{00 \& \mathrm{cl}=\mathrm{CL} 2.8 \& \mathrm{~d}=\mathrm{HASHc} 0 \mathrm{f} 452759080 \mathrm{ee} 9425 \mathrm{fb} 05.6}$ $\underline{1 \& g t=1}$
3. Civitarese, V., Pignatti, G., Verani, S., \& Sperandio, G. (2006). Pianificazione delle operazioni di esbosco in un ceduo. Forest@ - Journal of Silviculture and Forest Ecology 3(3), 367-375. https://doi.org/10.3832/efor0391-003036

4. Dangwal, D.D. (2005). Commercialisation of Forests, Timber Extraction and Deforestation in Uttaranchal 1815-1947. Conservation and Society, 3(1) 110-133. Available at https://www.jstor.org/stable/26396602

5. DGFP. (2004). "National forest and pastures inventory".

6. Eker, M. \& Acar, H.H. (1995). Gantner skyline for timber extraction in Turkish forestry.

7. Workshop on New Trends in Wood Harvesting with Cable Systems for Sustainable Forest Management in the Mountains, 121-128. Available at http://www.fao.org/3/Y9351E/Y9351E16.htm

8. Heinrich, R. (1998). Recent development on environmentally friendly forest road construction and wood transport in mountainous forests. Proceedings of the Seminar on Environmentally Sound Forest Roads and Wood Transport. Available at http://www.fao.org/3/X0622E/x0622e10.htm

9. Kaakkurivaara, N., \& Kaakkurivaara, T. (2018). Productivity and Cost Analysis of Three Timber Extraction Methods on Steep Terrain in Thailand. Croatian Journal of Forest Engineering, 39(2) 213221. Available at https://www.researchgate.net/publication/326632039 _Productivity_and_Cost_Analysis_of_Three_Timber _Extraction_Methods_on_Steep_Terrain_in_Thailan $\underline{\mathrm{d}}$

10. Kortoci, Y., \& Kortoci (Kellezi), M. (2020). Comparison of time consumption and productivity during beech forest felling and processing in two different working conditions. Bilge International Journal of Science and Technology Research, 4(1) 43-47. https://doi.org/10.30516/bilgesci.692307

11. Kortoci, Y. (2009). Le utilizzazioni forestali per una selvicoltura sostenibile nelle faggete albanesi. Available at https://docplayer.it/60177324-Leutilizzazioni-forestali-per-una-selvicoltura sostenibile-nelle-faggete-albanesi.html

12. Malinen, J., Laitila, J., Väätäinen, K., \& Viitamäki, K. (2016). Variation in age, annual usage and resale price of cut-tolength machinery in different regions of Europe. International Journal of Forest Engineering 27(2), 95-102. https://doi.org/10.1080/14942119.2016.1171964 
13. Ozturk, T., \& Senturk, N. (2006). Extraction of spruce timber by Gantner cable crane from selective forests of Artvin region. Croatian Journal of Forest Engineering, 27(1), 59-66. Available at https://hrcak.srce.hr/4000

14. Tadeusz, M., Stelian, A. B., Jiří, D., Michal, F., Sotir, G., Peeter, M., Andis, L., \& Oleg, S. (2017). Timber Harvesting Methods in Eastern European Countries: a Review. Croatian Journal of Forest Engineering 38(2), 231-241. Available at https://www.researchgate.net/publication/319902722 _Timber_Harvesting Methods in Eastern European Countries_a Review

15. Trzesnowski, A. (1998). Wood transport in steep terrain. Proceedings of the Seminar on Environmentally Sound Forest Roads and Wood Transport. Available at http://www.nzdl.org/cgibin/library?e=d-00000-00---off-0aginfo--00-0----010-0---0---0direct-10---4-------0-11--11-en-50---20about---00-0-1-00-0-0-11----0-0-

$\& \mathrm{a}=\mathrm{d} \& \mathrm{c}=\mathrm{aginfo} \& \mathrm{cl}=\mathrm{CL} 2.8 \& \mathrm{~d}=\mathrm{HASHc} 0 \mathrm{f} 45275908$ 0ee9425fb05.6.10\#HASHc0f452759080ee9425fb05. $\underline{6.10}$ 